\section{PENINGKATAN KEMAMPUAN APRESIASI CERPEN SISWA MELALUI TEKNIK ANALISIS UNSUR-UNSUR INTRINSIK}

\section{Nurmi}

SMA Negeri 2 Walenrang, South Sulawesi

Email:nurmi@gmail.com

http://ojs.unm.ac.id/index.php/Insani/index

Abstrak. Tujuan penelitian ini adalah meningkatkan daya apresiasi siswa terhadap karya sastra. Salah satu teknik yang dapat digunakan adalah dengan teknik analisis unsurunsur intrinsik. Berdasarkan hasil analisis data selama siklus I, II, dan III dapat disimpulkan hasil penelitian sebagai berikut: (1) jumlah siswa yang memiliki minat baca cerpen meningkat $(60 \%$ $70 \%$ ), (2) jumlah siswa yang memiliki kemampuan mengidentifikasi unsur-unsur intrinsik meningkat (40\% - 64\%), (3) jumlah siswa yang memiliki kemampuan menganalisis unsurunsur intrinsik meningkat (40\% - 60\%). Hasil penelitian juga menunjukkan adanya perubahan pada guru menjadi lebih peduli terhadap suasana kelas.

Kata Kunci : Media Pembelajaran, Aplikasi Android, Dimensi Tiga.

\section{INDONESIAN JOURNAL OF EDUCATIONAL STUDIES (IJES)}

\section{E-ISSN: 2621-6744 \\ P-ISSN: 2621-6736}

Submitted: December, $2^{\text {nd }} 2018$

Accepted : February, $2^{\text {nd }} 2018$

Abstract. The purpose of this study is to increase students' appreciation of literary works. One technique that can be used is the analysis of intrinsic elements. Based on the results of data analysis during cycles I, II, and III it can be concluded that the results of the study are as follows: (1) the number of students who have a short reading interest increases (60\% - 70\%), (2) the number of students who have the ability to identify elements intrinsic increases (40\% - 64\%), (3) the number of students who have the ability to analyze intrinsic elements increases (40\% - 60\%). The results of the study also showed that there was a change in teachers becoming more concerned about the classroom atmosphere. 


\section{PENDAHULUAN}

Pembelajaran sastra di sekolah hanya merupakan salah satu butir pembelajaran dalam mata pelajaran bahasa Indonesia. Sastra merupakan karya seni yang unsurunsur keindahannya menonjol. Salah satu unsur sastra itu adalah unsur-unsur intrinsik. Untuk memahami karya sastra, penguasaan terhadap unsur intrinsik merupakan salah satu hal yang tidak dapat diabaikan. Tujuan pengajaran sastra ditekankan demi terwujudnya kemampuan siswa untuk mengapresiasi sastra secara memadai.

Menurut data hasil pengumpulan tugas-tugas pada buku tugas siswa, sekurangkurangnya $70 \%$ siswa kelas $\mathrm{XI}-2$ di SMA Negeri 2 Walenrang tidak memiliki minat terhadap sastra, khususnya cerpen, kurang berminat membaca cerpen, kurang mampu dalam mengidentifikasi dan menganalisis berbagai unsur khas yang semuanya tercakup dalam wadah apresiasi. Teknik yang digunakan guru dalam pembelajaran apresiasi sastra (cerpen) adalah pemberian materi atau tugas-tugas yang hanya ditekankan pada aspek yang bersifat ingatan, hafalan, dan pemahaman terhadap hal-hal yang berkaitan dengan pengetahuan tentang sastra, bukan apresiasinya.

Berdasarkan permasalahan di atas, tujuan penelitian ini secara umum adalah untuk meningkatkan daya apresiasi (menyenangi) siswa terhadap cerpen pada siswa kelas XI-2 di SMA Negeri 2 Walenrang melalui teknik analisis unsur-unsur intrinsik. Sedangkan tujuan khusus pada akhir penelitian ini diharapkan daya apresiasi siswa terhadap cerpen mengalami peningkatan dengan indikator: (1) sekurang-kurangnya $70 \%$ siswa memiliki minat baca cerpen; (2) sekurang-kurangnya $60 \%$ siswa mampu mengidentifikasi unsur-unsur intrinsik cerpen; (3) sekurang-kurangnya 50\% siswa mampu menganalisis unsur-unsur intrinsik.

Hasil penelitian ini diharapkan mampu memberikan manfaat bagi siswa, guru, dan sekolah. Siswa akan membantu menciptakan daya apresiasi (menyenangi) cerpen. Guru dapat memperoleh tambahan alternatif pendekatan pembelajaran sastra dengan teknik analisis unsur-unsur intrinsik, memiliki tambahan pengetahuan dan pengalaman tentang teknik pembelajaran sastra. Di samping itu, guru akan menciptakan suasana kelas yang kondusif dalam pembelajaran sastra. Ini dilakukan sebagai bagian dari upaya perbaikan, perkembangan, dan peningkatan mutu pendidikan sekolah.

\section{KARYA SASTRA}

Karya sastra adalah karya seni yang berbicara tentang masalah hidup dan kehidupan, tentang manusia dan kemanusiaan yang menggunakan bahasa sebagai mediumnya (Esten, 1980). Seirama dengan itu (Rusyana, 1982) menyatakan bahwa sastra adalah hasil kegiatan kreatif manusia dalam pengungkapan penghayatannya tentang hidup dan kehidupan, tentang manusia dan kemanusiaan yang menggunakan bahasa. Dari kedua pendapat itu dapat ditarik makna bahwa karya sastra adalah karya seni, mediumnya (alat penyampainya) adalah bahasa, isinya adalah tentang manusia, bahasannya adalah tentang hidup dan kehidupan, tentang manusia dan kemanusiaan. Pembelajaran sastra tidak dapat dipisahkan dengan 
pembelajaran bahasa. Namun, pembelajaran sastra tidaklah dapat disamakan dengan pembelajaran bahasa. Perbedaan hakiki keduanya terletak pada tujuan akhirnya.

Menurut (Oemarjati, 1992) pengajaran sastra pada dasarnya mengemban misi efektif, yaitu memperkaya pengalaman siswa dan menjadikannya lebih) tanggap terhadap peristiwa-peristiwa di sekelilingnya. Tujuan akhirnya adalah menanam, menumbuhkan, dan mengembangkan kepekaan terhadap masalah-masalah manusiawi, pengenalan dan rasa hormatnya terhadap tata nilai, baik dalam konteks individual, maupun sosial. Apresiasi sastra merupakan kegiatan menggauli karya sastra secara sungguh-sungguh sehingga menumbuhkan pengertian, penghargaan, kepekaan, pikiran kritis, dan kepekaan perasaan yang baik terhadap karya sastra. Menurut Roestam Effendi dkk. (1998) bahwa apresiasi adalah kegiatan mengakrabi karya sastra secara sungguh-sungguh. Di dalam mengakrabi tersebut terjadi proses pengenalan, pemahaman, penghayatan, penikmatan, dan setelah itu penerapan. Kesungguhan dalam kegiatan tersebut akan menuju tingkat pemahaman. Pemahaman terhadap karya sastra akan membuat penghayatan. Indikator yang dapat dilihat setelah menghayati karya sastra adalah jika bacaan, dengaran, atau tontonan sedih ia akan ikut sedih, jika gembira ia ikut gembira, begitu seterusnya. Hal itu terjadi seolah-olah ia melihat, mendengar, dan merasakan dari yang dibacanya. la benar-benar terlibat dengan karya sastra yang digeluti atau diakrabinya.

Hal ini juga ditegaskan oleh Sayuti (2009) bahwa apresiasi sastra merupakan hasil usaha pembaca dalam mencari dan menemukan nilai hakiki karya sastra lewat pemahaman dan penafsiran sistematik yang dapat dinyatakan dalam bentuk tertulis. Dari kedua pendapat di atas, dapat disimpulkan bahwa kegiatan apresiasi dapat tumbuh dengan baik apabila pembaca merasa akrab dengan teks sastra yang diapresiasinya, bersikap sungguh-sungguh serta melaksanakan kegiatan apresiasi itu sebagai bagian dari hidupnya, sebagai suatu kebutuhan yang mampu merumuskan rohaninya (Aminudin, 2009:35).

Terdapatnya berbagai unsur dalam karya sastra mengimplikasikan bahwa untuk mengapresiasi cipta sastra, pembaca pada dasarnya dipersyaratkan memiliki bekalbekal tertentu. Bekal awal yang harus dimiliki adalah (1) kepekaan emosi atau perasaan sehingga pembaca mampu memahami dan menikmati unsur-unsur keindahan yang terdapat dalam cipta sastra, (2) pemilihan pengetahuan dan pengalaman yang berhubungan dengan masalah kehidupan dan kemanusiaan, baik lewat penghayatan kehidupan ini secara intensif-kontemplatif maupun dengan membaca buku-buku yang berhubungan dengan masalah humanitas, (3) pemahaman terhadap aspek kebahasaan, dan (4) pemahaman terhadap unsur-unsur intrinsik cipta sastra yang akan berhubungan dengan telaah teori sastra (Aminudin, 2009:38).

\section{METODE PENELITIAN}

Penelitian tindakan kelas ini dilaksanakan untuk mata pelajaran Bahasa Indonesia pada kelas XI-2 di SMA Negeri 2 Walenrang. Siswa kelas ini kurang mampu mengidentifikasi dan menganalisis unsur-unsur intrinsik. Dalam proses pembelajaran sastra, siswa masih banyak yang bersikap pasif. Sebelum pelaksanaan penelitian tindakan kelas dimulai, dibuatlah beberapa instrumen untuk mendukung proses penelitian. Instrumen-instrumen tersebut antara lain: 
1. Angket

Angket digunakan untuk mengukur daya apresiasi siswa. Daftar pertanyaan diberikan kepada siswa untuk mengetahui gambaran permasalahan yang dihadapi dalam pembelajaran sastra. Siswa menjawab pertanyaan dengan pilihan jawaban yang sudah tersedia sesuai dengan keadaan yang dihadapi.

2. Pedoman Wawancara

Pedoman wawancara digunakan oleh guru mitra terhadap guru peneliti sebelum perlakuan penelitian. Kegiatan ini dimaksudkan untuk memperoleh gambaran permasalahan kegiatan pembelajaran sastra.

3. Lembar Observasi Guru

Lembar ini digunakan untuk memperoleh data tentang kegiatan yang dilakukan oleh guru dalam proses pembelajaran. Observer mengamati dan mencatat segala permasalahan yang terjadi.

4. Lembar Observasi Siswa

Instrumen ini digunakan untuk memperoleh data dari siswa yang sedang melakukan tindakan apresiasi cerpen. Peneliti mencatat segala permasalahan yang terjadi, baik siswa yang ikut terlibat aktif, maupun yang tidak.

5. Analisis Portofolio

Hasil pekerjaan siswa dalam setiap tahapan dikumpulkan dan dianalisis. Berdasarkan analisis hasil pekerjaan siswa, akan dapat diketahui tingkat keefektifan penerapan teknik analisis unsur-unsur intrinsik pada suatu tahapan tertentu. Peneliti bersama-sama dengan tim peneliti yang lain mengadakan pemeriksaan hasil pekerjaan siswa dan menganalisis serta menentukan keberhasilan individu ataupun kelompok.

Prosedur penelitian tindakan kelas ini dilaksanakan sesuai dengan perubahan yang ingin dicapai. Untuk dapat melihat peningkatan minat siswa, kemampuan mengidentifikasi dan menganalisis unsur-unsur intrinsik, maka diadakan evaluasi. Dari hasil evaluasi, diadakan analisis dan refleksi sehingga dapat dicarikan solusi untuk mengatasi masalah. Pelaksanaan tindakan ini dilakukan dengan menggunakan tiga siklus yang masing-masing teridri dari perencanaan, pelaksanaan, pengamatan, dan refleksi.

\section{HASIL DAN PEMBAHASAN}

Penelitian tindakan kelas ini dilaksanakan sesuai dengan perubahan yang ingin dicapai. Observasi dilakukan untuk mengetahui tindakan yang tepat dalam menentukan teknik pembelajaran. Dari hasil evaluasi dan observasi awal diterapkan tindakan untuk membantu siswa dalam mengapresiasi cerpen dengan teknik analisis unsur-unsur intrinsik. Dengan berpedoman pada hasil refleksi, pelaksanaan tindakan ini dilakukan dengan menggunakan tiga siklus.

\section{Siklus Pertama}

1) Perencanaan

Langkah-langkah pada tingkat perencanaan ini adalah sebagai berikut:

- Membuat rencana pembelajaran dengan menggunakan teknik analisis unsurunsur intrinsik dengan tahapan: menyiapkan cerpen, membaca cerpen, mengidentifikasi, dan menganalisis; 
- Membuat lembar observasi untuk mengetahui bagaimana kondisi belalarmengajar di kelas ketika teknik analisis unsur-unsur intrinsik ini diterapkan;

- Menyediakan bahan ajar berupa cerpen;

- Membuat alat evaluasi

2) Pelaksanaan

Pada akhir penelitian, diharapkan daya apresiasi siswa terhadap cerpen mengalami peningkatan dengan kriteria:

- Sekurang-kurangnya 70\% siswa memiliki minat baca terhadap cerpen;

- Sekurang-kurangnya 60\% siswa mampu mengidentifikasi unsur-unsur intrinsik cerpen;

- Sekurang-kurangnya 50\% siswa mampu menganalisis unsur-unsur intrinsik cerpen.

Berdasarkan data yang diperoleh dengan instrumen pengukur peningkatan daya apresiasi siswa terhadap cerpen dan instrumen kegiatan gemar membaca cerpen, dapat diketahui bahwa minat baca siswa terhadap cerpen baru mencapai $60 \%$. Ini berarti belum sesuai dengan kriteria yang telah ditetapkan. Dari data yang diperoleh tersebut, dapat disimpulkan bahwa apa yang telah direncanakan pada kriteria pertama belum bisa direalisasikan secara penuh sesuai dengan kriteria yang telah ditetapkan.

Berdasarkan analisis hasil pekerjaan siswa dalam refleksi, maka dapat diketahui persentase hasil pencapaian siswa terhadap kriteria kedua baru mencapai sekitar 40\%. Dapat disimpulkan bahwa siswa belum mampu/ berhasil untuk mengidentifikasi unsur-unsur intrinsik dalam cerpen sesuai dengan kriteria yang telah ditetapkan.

Pada tahap pelaksanaan siklus I kriteria ketiga dapat diuraikan sebagai berikut: Berdasarkan analisis hasil pekerjaan siswa dengan melalui refleksi, maka dapat diketahui persentase hasil pencapaian siswa terhadap kriteria ketiga baru mencapai sekitar 40\%. Dapat disimpulkan bahwa siswa belum mampu/ berhasil untuk menganalisis unsur-unsur intrinsik dalam cerpen sesuai dengan kriteria yang telah ditetapkan.

3) Pengamatan

Berdasarkan hasil observasi terhadap berbagai instrumen yang digunakan, dapat diuraikan ketercapaian masing-masing instrumen.

- Melalui lembar observasi untuk mengukur tingkat keaktifan siswa dalam proses belajar-mengajar, bahwa dari 45 siswa kelas XI-2, siswa yang ikut terlibat aktif sekitar $64,3 \%$. Kegiatan pengambilan data ini dilakukan oleh guru mitra (observer) yang melakukan pengamatan terhadap jalannya proses belajar-mengajar di kelas dengan segala permasalahan yang terjadi.

- Instrumen monitoring observasi kelas digunakan untuk mengetahui sejauh mana efektivitas proses pembelajaran yang dilakukan oleh guru. Berdasarkan kesimpulan yang dibuat oleh guru mitra tentang keberhasilan pembelajaran, dapat diketahui bahwa proses pembelajaran yang dilakukan oleh guru peneliti dikategorikan baik. Hal ini berdasarkan perhitungan dengan menggunakan skala nilai yang sudah ditetapkan. 
- Analisis portofolio yang dikumpulkan dalam setiap tahapan pada siklus I ini menunjukkan bahwa data kuantitatif yang diperoleh siswa belum sesuai dengan kriteria yang telah ditetapkan.

4) Refleksi

Dengan mengacu pada instrumen pengukur tingkat ketercapaian daya apresiasi (menyenangi) siswa terhadap cerpen yang merupakan rekapitulasi hasil kegiatan siswa selama tahapan siklus tertentu, dapat diketahui bahwa pada siklus I ini ternyata persentase hasil ketercapaian belum sesuai dengan kriteria peningkatan yang sudah ditetapkan. Ini berarti perlu dilanjutkan lagi pada siklus berikutnya.

\section{Siklus Kedua}

1) Perencanaan

Langkah-langkah kegiatan perencanaan dalam siklus II ini sama dengan kegiatan yang dilakukan pada siklus I.

2) Pelaksanaan

Berdasarkan data yang diperoleh melalui observasi terhadap instrumen untuk mengukur peningkatan daya apresiasi siswa terhadap cerpen dan instrumen kegiatan gemar membaca cerpen, dapat diketahui bahwa minat baca siswa terhadap cerpen telah mencapai 70\%. Ini berarti hasil yang diperoleh sudah sesuai dengan kriteria yang telah ditetapkan. Dari data yang diperoleh tersebut, dapat disimpulkan bahwa apa yang telah direncanakan pada kriteria pertama bisa direalisasikan sesuai dengan kriteria yang telah ditetapkan.

Pada tahap pelaksanaan siklus II, kriteria ketiga dapat diuraikan sebagai berikut:

Berdasarkan analisis hasil pekerjaan siswa, dapat diketahui bahwa persentase hasil pencapaian siswa terhadap kriteria ketiga telah mencapai sekitar $60 \%$. Sehingga dapat disimpulkan bahwa siswa telah mampu/ berhasil untuk menganalisis unsur-unsur intrinsik dalam cerpen sesuai dengan kriteria yang telah ditetapkan.

3) Pengamatan

Berdasarkan hasil observasi terhadap berbagai instrumen yang digunakan, dapat diuraikan ketercapaian masing-masing instrumen sebagai berikut:

- Melalui lembar observasi untuk mengukur tingkat keaktifan siswa dalam proses belajar-mengajar, dapat diketahui bahwa dari sejumlah 45 siswa kelas $\mathrm{XI}-\mathrm{C}$, yang ikut terlibat aktif sekitar $60 \%$. Kegiatan pengambilan data ini dilakukan oleh guru mitra (observer) yang sedang melakukan pengamatan terhadap jalannya proses belajar-mengajar di kelas dengan segala permasalahan yang terjadi.

- Instrumen monitoring observasi kelas digunakan untuk mengetahui sejauh mana efektivitas pembelajaran yang dilakukan oleh guru. Berdasarkan kesimpulan yang dibuat oleh guru mitra tentang keberhasilan pembelajaran, dapat diketahui bahwa proses pembelajaran yang dilakukan oleh guru peneliti dikategorikan baik. Hal ini berdasarkan perhitungan dengan menggunakan skala nilai yang telah ditetapkan. 
- Analisis portofolio yang dikumpulkan dalam setiap tahapan pada siklus II ini menunjukkan bahwa data kuantitatif yang diperoleh siswa telah memenuhi kriteria yang telah ditetapkan.

4) Refleksi

Dengan mengacu pada instrumen pengukur tingkat ketercapaian daya apresiasi (menyenangi) siswa terhadap cerpen yang merupakan rekapitulasi hasil kegiatan selama tahapan siklus tertentu, dapat diketahui bahwa pada siklus II ini, persentase hasil ketercapaian sudah memenuhi/ sesuai dengan kriteria peningkatan yang sudah ditetapkan.

\section{Siklus Ketiga}

Pelaksanaan tindakan pada siklus III ini menggunakan prosedur yang sama dengan siklus-siklus sebelumnya, yaitu perencanaan, pelaksanaan, pengamatan, dan refleksi. Tindakan keempat prosedur pada siklus III ini hanya merupakan pemantapan dan penekanan kembali atas hasil yang sudah diperoleh pada siklus II, karena siklus II dianggap telah memenuhi kriteria yang telah ditetapkan.

\section{KESIMPULAN}

Para siswa pada umumnya mengalami kesulitan dalam menumbuhkan sikap apresiasi terhadap karya sastra. Oleh karena itu, agar kesulitan ini dapat diatasi, sangat perlu diajukan suatu teknik yang mampu menuntun dan mampu mengarahkan siswa. Salah satu teknik yang dapat digunakan adalah teknik analisis unsur-unsur intrinsik. Teknik analisis ini dapat memudahkan dan meningkatkan daya apresiasi siswa tehadap karya sastra karena dengan analisis unsur-unsur intrinsik, siswa pada umumnya akan menyadari bahwa cipta sastra itu pada dasarnya diwujudkan lewat kegiatan yang serius dan terencana, sehingga tertanamlah rasa penghargaan atau sikap yang baik terhadap karya sastra. Dalam pelaksanaannya, teknik analisis unsurunsur intrinsik ini diawali dengan kegiatan membaca teks atau karya sastra. Setelah itu, siswa menampilkan beberapa pertanyaan yang berhubungan dengan unsurunsur intrinsik yang membangun cipta sastra yang dibacanya.

\section{DAFTAR PUSTAKA}

A. Sayuti. S. (2009). Teks Sastra. Yogyakarta: Universitas Negeri Yogyakarta. Aminudin. (2009). Pengantar apresiasi karya sastra. Bandung : Sinar Baru.

Broto, A.S. (1992). Metodologi proses belajar-mengajar berbahasa. Sala : Tiga Serangkai.

Nurdiantoro, B. (1988). Penilaian dalam Pengajaran Bahasa dan Sastra. Yogyakarta : BPEE.

Sumarjo, J. \& K.M. Saini. (1988). Apresiasi Kesusastraan. Jakarta : Gramedia 